\title{
A Preliminary Study on the Construction of Innovation and Entrepreneurship Curriculum System of Social Sports Students
}

\author{
Cao Jia \\ School of Physical Education, Baicheng Normal University, Baicheng, 137000, China \\ wushucaojia@163.com
}

Keywords: Social sports major, Innovation and entrepreneurship, Curriculum, Construction

\begin{abstract}
With the innovation and development of social economy, colleges and universities are required to train applied talents. On the other hand, the development of mass education brings more challenges to the educational and teaching activities in colleges and universities. How to realize the innovation and development of various specialties in colleges and universities, and how to cultivate creative talents in all aspects of society is extremely urgent. The students of social sports specialty have strong professional characteristics and have certain limitations in the early development. Therefore, this paper explores the development of the education and teaching activities for the students of social sports majors, and has important reference value for other professional education activities in colleges and universities. Based on this, this paper mainly starts with the current situation of education and teaching for students majoring in social sports, analyzes the importance of the construction of Innovation and entrepreneurship curriculum for students majoring in social sports, and finally probes into the channels for constructing the curriculum system of innovation and entrepreneurship for students majoring in social sports.
\end{abstract}

\section{Introduction}

At present, the transformation and development of China industrial structure has reached a critical stage, which requires the realization of the transformation and development of marginal industries, the cultivation of more innovative talents in colleges and universities, and the integrated development of industry, university and research is not only aimed at technical specialties, but also at some social sciences majors. For the social sports major, in the course arrangement of many colleges and universities, the social sports major is more inclined to train the sports professional talents, and the students of the social sports major tend to be the sports training teacher and run the physical education training institution after graduation, that is of great significance to the career development of the students in this major, but in the long run, simply realizing the employment development of the training institutions will limit the long-term development of the major. Therefore, it is required to be able to construct the curriculum system of innovation and entrepreneurship for students majoring in social sports, train students innovative spirit and ability, and ultimately promote the development of social sports.

\section{Current Situation of Education and Teaching for Students Majoring in Social Physical Education}

\subsection{Present Situation of Employment and Development of Social Sports Major Students.}

The present employment situation of students majoring in social sports directly affects whether to realize the reform and innovation of the curriculum of social sports major. For the entrepreneurship curriculum system, more and more colleges and universities focus on technical majors, such as computer, agricultural technology and so on. For the humanities and social sciences, innovative entrepreneurial guidance and projects is lack. The main employment direction of the major of social sports is to engage in the organization, management, consultation, guidance, experience development and teaching and scientific research of mass sports activities in the field of 
social sports. At present, the employment of students majoring in social sports presents two characteristics. First, the employment of students majoring in social sports presents a polarization of development. More students focus on the employment of education and training institutions, this kind of employment for the use of the highest rate of professional, and pay, the future development plan is clear, and it is the primary choice of most students; A small number of students are concentrated in other professional fields of social sports, such as joining the sales of sports related industries or entering into the health related industries. In short, the employment of students majoring in social sports is not optimistic. Second, the employment of students majoring in social sports has a larger development interval. With the development of national sports slogan, mass sports economy has gradually become the main source of the national economy [1]. As the main discipline of mass sports economy, the social sports specialty has a broad development space. With the development of social economy and group sports, more employment opportunities have been brought to the students majoring in social sports. Most of the employment opportunities are engaged in the sales work of group sports related industries, as well as in educational and training institutions. The salary is mainly more than 7000 yuan, the cities with more employment opportunities are concentrated in the first tier cities with developed economy, and the employment opportunities in the second and third tier cities are less, and the salary of students after employment is far lower than the employment opportunities in the first tier cities. At present, it can be said that the employment of social students shows a one-sided phenomenon, the overall development trend is not clear. It is a necessary choice for the sustainable development of social sports major to realize the arrangement of innovation and entrepreneurship curriculum for this major.

\subsection{Present Situation of Curriculum Arrangement for Students Majoring in Social Physical Education.}

First, the social sports major student curriculum arrangement has the extensive nature. The main courses for the students majoring in social sports in traditional teaching activities are the introduction of social sports, the management of social sports, the general introduction to national fitness, the theory and method of sports and health care, the theory and method of Chinese sports health preservation and mass fitness and entertainment sports. Introduction to sports scientific research methods, theories and methods of sports events, etc., the above curriculum arrangement shows the characteristics of parallel theory and method, and has a large subject category, such as group sports economy, health management and so on. The specialty has the characteristic of deep and excavable discipline. But in other words, in three years, it is very difficult that social sports students are required to complete a number of disciplines, and have a certain depth of research. Second, the curriculum arrangement of social sports majors has the characteristics of innovation and entrepreneurship. Learning a single course content is not conducive to the individual development of students. For the students majoring in social sports, the establishment of diversified curriculum contents provides more choices for the students employment direction, and also provides more economic points for the innovative talents training plan launched by the school. As far as the curriculum arrangement for the major of social sports is concerned, the Chinese sports science of health preservation can be seen as a good innovation point through the promotion of the current society on the subject of health preservation. Through the study of the content of the course, the students can develop the course into an innovative start - up point. All in all, the social sports professional curriculum requires their professional curriculum to realize the innovation and development in terms of the students undefined employment, join the necessary innovation and entrepreneurship curriculum system and realize the students undefined comprehensive development [2]. 


\section{The Necessity of Constructing the Innovation and Entrepreneurship Curriculum System of social sports students}

\subsection{The Impact of Innovation and Entrepreneurship Curriculum System on Students Individual.}

At the end of the last century, foreign higher education teaching activities require the construction of innovative and entrepreneurial curriculum system. The aim is to cultivate the most pioneering people, including pioneering spirit, adventurous spirit, entrepreneurial spirit, independent working ability, and the cultivation of technology, society and management skills. The curriculum system of innovation and entrepreneurship is the comprehensive cultivation of students pioneering spirit, innovation spirit, various skills and management ability. For the students, it is the channel to cultivate talents. The construction of innovative and entrepreneurial curriculum system in university majors can lead students to grasp the current industry environment actively, make students master the requirements of personal basic qualities under the development of the times, and cultivate students critical thinking to meet the challenges of society calmly.

\subsection{The Impact of Innovation and Entrepreneurship Curriculum System on Social Development.}

In "opinions on vigorously promoting innovation and entrepreneurship education in colleges and universities", the positive role of innovative entrepreneurship education in school development and social development is emphasized many times. Only when schools attach importance to innovative entrepreneurial education activities and construct innovative entrepreneurship education system can they cultivate professional talents, realize professional development, ensure the competitiveness of schools in comprehensive strength, and social development needs talents. More jobs need to be created, and only by boosting entrepreneurship to create more jobs can society be stable and peaceful, and the national economy rise steadily. Therefore, it is urgent to construct the curriculum system of innovation and entrepreneurship for the development of individual, the development of school and the development of society [3].

\section{Constructing Channels of the Innovation and Entrepreneurship Curriculum System of Social Sports Students}

According to the above, the construction of innovation and entrepreneurship curriculum system for social sports students is the key to the development of colleges and universities. The implementation of the system must start from the following aspects:

\subsection{Schools Should Grasp the Contents of Innovation and Entrepreneurship Curriculum System for Social Sports Students.}

The construction of innovative and entrepreneurship curriculum system is the key to the development of various majors in colleges and universities, but different professional development needs different curriculum system content. On the whole, the contents of the innovative and entrepreneurship curriculum system are similar to each other, and the main content is to train the students in four aspects, which are as follows: The cultivation of consciousness requires students to master the basic consciousness and basic knowledge of entrepreneurial activities. For example, the students majoring in social sports should master the basic information of their major, develop the consciousness of innovation, start an undertaking, and possess the management consciousness of modern enterprises; Ability development requires the cultivation of students critical thinking, organization and coordination ability and leaders ability. Only when students have the ability of superior person and make overall consideration to entrepreneurial activities can they realize real entrepreneurial activities; Environmental cognition training, entrepreneurial activities are based on the development of different industries and regions, for different economic levels and development degree of the region, different entrepreneurial projects development space is different, Therefore, it is required to incorporate environmental cognition into the contents of innovative entrepreneurship 
curriculum system, to guide students to correctly understand the saturated state of social sports major in the first and second tier cities, while the third and fourth tier cities are in the stage of development. In order to grasp the risk of entrepreneurship, business model development process, design strategies and skills, etc; Practice simulation, in the course system of innovative entrepreneurship, the cultivation and education of practice simulation is of great importance, mainly through the simulation of entrepreneurial activities, so that students can master the market evaluation, financing activities and possible risks of every entrepreneurial project of social sports specialty in advance. In a word, it is necessary to integrate the main contents of professional entrepreneurship and to develop the specialized training of the system content in order to construct the innovation and entrepreneurship curriculum system for students majoring in social sports [4].

\subsection{Constructing of the Innovation and Entrepreneurship Curriculum System for Social Sports Students Needs to Respect the Personality Development of Students.}

For the students majoring in social sports, they have the same characteristics, that is, their professional knowledge is poor. Therefore, this kind of students have some shortcomings, that is, the deficiencies of other knowledge systems, such as the relevant knowledge about management, the relevant knowledge about computers and the Internet. It is inevitable to present the problem of lack of ability and vision. Therefore, the innovation and entrepreneurship curriculum system for social sports students can be divided into two stages. The first stage belongs to the popular innovative entrepreneurship curriculum, that is, every student needs to be exposed to the innovative entrepreneurship course, and initially develop the awareness and concept of entrepreneurship, that is, entrepreneurship is also a direction for future employment. And the business is not blindly follow the class but the need for innovation and development. This literacy stage is important to all students majoring in social sports. Some students who are confused about the future can also find the way forward through innovative entrepreneurial courses. At the same time, the learning suggestion of this stage is to realize the curriculum arrangement without major distinction, such as realizing the large-class teaching of combining the social sports major with the management major students, so that the students with different specialty characteristics can form the connection to provide a new direction of innovation for social sports major entrepreneurship[5]; The second stage is the introduction of a professional curriculum for innovation and entrepreneurship, whereby interested students begin their own study of innovative entrepreneurship courses through elective courses. Moreover, teachers can also develop in-depth entrepreneurship courses by combining students with different majors of interest. If some students of social sports major are interested in sports economy and computer technology, they can realize the connection of the two majors and provide more opportunities for students to innovate. In a word, we should adopt a gradual approach to realize the curriculum system of social sports students innovation and entrepreneurship, and not force the students who do not have the consciousness and idea of innovation to carry out the in-depth study of innovative entrepreneurship courses, which can realize the individualized educational activities and also provides more opportunities for capable and thoughtful students.

\subsection{The Combination of Theory and Practice is Needed to Construct the Innovation and Entrepreneurship Curriculum System for Social Sports Students.}

No matter which major the curriculum system of innovation and entrepreneurship can not be separated from practical operation. At present, the most common course arrangements for innovative entrepreneurship practice are to use the method of simulating entrepreneurship, to launch entrepreneurial activities through simulation on the website, to give entrepreneurial students some capital to start new projects themselves to achieve business in a certain period of time. In this process, although the risks such as financing problems, capital management problems and so on can be simulated to improve students management ability, the simulated practical activities lack the dynamic variability in the process of actual entrepreneurship [6]. Therefore, social sports students are required to innovate entrepreneurship curriculum system to provide students with specific and detailed practical activities. If the university creates a fund for college students, it will provide the students with a start-up fund of 30,000 yuan, so that students can choose good entrepreneurial 
projects under the guidance of their mentors, carry out entrepreneurial practice activities, and realize the development of innovative entrepreneurship. Specific entrepreneurial operation can give students more experience education and warning in the future innovative entrepreneurial activities.

\section{Conclusion}

To sum up, according to the investigation of various kinds of documents and facts, it can be seen that the current curriculum design of social sports majors is mainly based on basic courses, such as cultural basic courses, professional basic courses, innovative entrepreneurship courses, etc. The single category seriously affects the students' absorption and mastery of the innovative and entrepreneurial curriculum, which leads to the poor employment ability of the students majoring in social sports, the poor economic type of the subject, the low feedback of the subject, and so on. Under the background of the current technical environment, the construction of the innovation and entrepreneurship curriculum system for social sports students can be started from many aspects. The first is that the relevant departments attach importance to the innovative and entrepreneurial development of humanities and social sciences majors. Ideologically, it ensures that humanities and social sciences can also achieve entrepreneurial development, rather than providing basic labor for society. Second, it is necessary to go to school to realize various forms of entrepreneurship teaching, set up professional entrepreneurship guidance courses and so on, such as using the form of cooperation between schools and enterprises. Third, it is to hire the relevant sectors of the community innovative entrepreneurs to launch employment guidance. Finally, the construction of the innovation and entrepreneurship curriculum system for social sports students is realized, and the long-term development of social sports majors is promoted.

\section{References}

[1] Du Zhaohui. Discussion about constructing of the innovation and entrepreneurship curriculum system for social sports students [J].Course Education Research, 2018(12):3-4.

[2] Yang Yang.A preliminary study on the construction of curriculum system of social sports students innovation and entrepreneurship [J]. Contemporary Sports Technology, 2017, 7(31): 126-127.

[3] Wang Minqiang, Jiang Chao. Construction of applied Talent training model for social sports major in independent college [J].Guangxi Journal of Light Industry, 2016(31):165-167.

[4] Xu Shijun. Thinking about the training Mode of Social Sports Specialty [J].Guangxi Journal of Light Industry, 2015(19):161-163.

[5] Zhang Daoqing, Chen Shigao, Lei Ming. The construction of entrepreneurial education curriculum system for social sports specialty in colleges and universities [J]. Academy, 2014(14): 8-9.

[6] Li Xianguo. Analysis and Research on the present situation of the Curriculum system of Colleges and departments of physical Education in Anhui Province [J]. Sports teacher friend, 2012, 35(06): 70-72. 